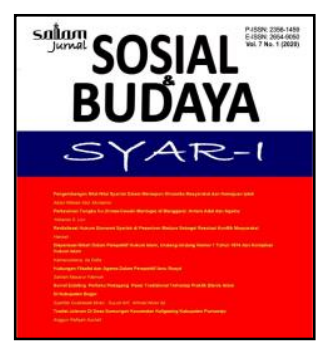

\title{
Pendapatan Dasar Melalui Bantuan Sosial PKH Sebagai Upaya Peningkatan Ekonomi Masyarakat Miskin: Studi Kasus Analisis Kapital Sosial Masyarakat Dusun Sade, Lombok, NTB*
}

\author{
Muhammad Imam Saputra \\ Departemen Ilmu Kesejahteraan Sosial, FISIP UI \\ d. \\ $\underline{10.15408 / \mathrm{sjsbs} . v 8 \mathrm{i} 4.21006}$
}

Abstract

\begin{abstract}
The existence of good relations through a close level of trust in the formation of social capital between the community and the government will increase the success of a program. The government's understanding of the real needs of the community, the community is also able to optimize program interventions which will result in work harmony between the government and the community. The fulfillment of basic needs which is the main polemic can be met with social security with the concept of a pendapatan dasar. The existence of this idea is expected to increase public confidence in the government. The income obtained through social assistance in the form of cash will provide unconditional life insurance which will later change the mindset and behavior of the community in applying other assistance programs. This meeting point will later answer the global challenge in mobilizing the community to continue to carry out production activities. This study uses a qualitative approach which is located in the tourism area of Dusun Sade, Lombok. In-depth interviews were conducted with representatives of indigenous peoples, traditional leaders and representatives from the government. The information to be obtained is the certainty of social assistance that is able to increase the trust of the people of Sade Hamlet and the government is optimizing the social assistance program as a form of government effort to reactivate the economy in Sade Hamlet Keywords: Basicn Income; Social Capital; Indigenous People; Sade Hamlet
\end{abstract}

\begin{abstract}
Abstrak
Adanya hubungan baik melalui tingkat kepercayaan yang erat dalam pembentukan kapital sosial antara masyarakat dengan pemerintah akan meningkatkan keberhasilan suatu program. Pemahaman pemerintah akan kebutuhan riil masyarakat dan sebaliknya masyarakat mampu mengoptimalkan intervensi program mampu menghasilkan keselarasan kerja antara pemerintah dengan masyarakat. Pemenuhan kebutuhan dasar yang menjadi polemik utama dapat dipenuhi dengan jaminan sosial yang berkonsep pada pendapatan dasar yang universal. Adanya gagasan ini diharapkan mampu meningkatkan kepercayaan masyarakat akan pemerintah. Pendapatan yang didapatkan melalui bantuan sosial berbentuk cash akan memberikan jaminan hidup tanpa syarat yang nantinya akan mengubah pola pikir dan perilaku masyarakat dalam mengaplikasikan program bantuan lainnya. Titik temu inilah yang nantinya menjawab tantangan global dalam memobilisasi masyarakat untuk terus melakukan aktivitas produksi. Studi ini menggunakan pendekatan kualitatif yang berlokasi di kawasan pariwisata Dusun Sade, Lombok. Wawancara mendalam dilakukan kepada perwakilan masyarakat adat, tokoh adat dan perwakilan dari pemerintah. Informasi yang ingin didapat berupa kepastian bantuan sosial yang mampu meningkatkan trust/kepercayaan masyarakat Dusun Sade dan pemerintah mengoptimalkan program bantuan sosial sebagai bentuk upaya pemerintah menggerakkan kembali perekonomian di Dusun Sade.

Kata Kunci: Kapital Sosial; Pendapatan Dasar; Masyarakat Adat; Dusun Sade
\end{abstract}

* Received: May 03, 2021, Revision: May 25, 2021, Published: August 5, 2021. 


\section{A. PENDAHULUAN}

Kapital sosial merupakan entitas yang tercipta atau diciptakan sesuai dengan faktor-faktor internal dan eksternal suatu masyarakat. ${ }^{1}$ Kapital sosial juga yang menjadikan suatu masyarakat mampu bergerak ke arah yang lebih baik atau bahkan hanya menyebabkan kemunduran karena adanya suatu kepercayaan yang menyebabkan masyarakat kesulitan dalam mengembangkan potensi mereka. ${ }^{2}$ Bank dunia pernah mengulas tentang hubungan kapital sosial dengan pertumbuhan ekonomi walaupun dalam tingkatan mikro namun itu membuat argumentasi bahwa kapital sosial sedikit tidaknya mampu menggerakkan individu atau kelompok untuk meningkatkan perekonomian. ${ }^{3}$ Kritikan terhadap kebijakan pemerintah oleh para ekonom juga terkait pada kapital sosial pemerintah dengan masyarakat, bagaimana kebijakan tersebut dapat berhasil melalui kepercayaan atau trust. Kepercayaan masyarakat atas negara, membuat negara kuat dan sebaliknya. Begitu pula kapital sosial mampu menggerakkan kawasan industri atau kawasan pariwisata yang akhir-akhir ini menjadi salah satu isu hangat di kawasan berkembang seperti di Indonesia dan salah satunya adalah kawasan pariwisata di Nusa Tenggara Barat (yang selanjutnya disebut NTB).

Berhasil tidaknya intervensi pemerintah dalam mengupayakan pemercepatan peningkatan ekonomi di kawasan pariwisata tingkat daerah sedikitnya ada peran kapital sosial. ${ }^{4}$ Penerimaan program hingga pada pelaksanaan tentunya ada kesepakatan dan kesepahaman antara masyarakat dengan pemerintah. Oleh karenanya kapital sosial membahas mengenai eksistensi modal yang dapat mempengaruhi tumbuhnya perekonomian. Kapital sosial berbicara mengenai hubungan sosial, norma sosial dan tingkat kepercayaan. ${ }^{5}$ Terlebih kawasan daerah pariwisata didaerah cukup unik dan kebiasaan-kebiasaan adat istiadat yang berbeda akan mempengaruhi tingkat keberhasilan suatu program. Sama halnya pada Kabupaten Lombok Tengah dimana Dusun Sade yang merupakan dusun pariwisata memiliki angka kemiskinan sudah mencapai 147 ribu orang dengan populasi penduduk 912.879 ribu orang yang pada dua tahun sebelumnya angka kemiskinan mencapai angka 145 ribu.

Pemerintah harus mampu menjawab persoalan yang dilematis ini, program yang baik harusnya mampu disampaikan dengan baik untuk mencapai tujuan yang baik. Kapital sosial sangat menentukan perilaku masyarakat, setidaknya pemerintah melalui perwakilannya mampu mengembangkan delivery service system yang baik dan

${ }^{1}$ Deepa Narayan dkk., “Measuring Social Capital: An Integrated Questionnaire”, World Bank Publication, 2004, hlm.4.

${ }^{2}$ Francis Fukuyama, Trust: The Social Virtues And The Creation Of Prosperity (New York: Free Press, 1995), hlm.86-87.

${ }^{3}$ James Midgley, Social Development: The Developmental Perspective in Social Welfare (London: Thousand Oaks, 1995), hlm. 10.

${ }^{4}$ Semih Akcomak, The impact of social capital on economic and social outcomes (Netherlands: Universitaire Pers Maastricht, 2008), hlm.34-35.

${ }^{5}$ Robert Putnam, Bowling Alone: America's Declining Social Capital (United Stated: Journal of Democracy, 1995), hlm. 67. 
sesuai dengan nilai masyarakat setempat. ${ }^{6}$ Pengembangan kapital sosial harus dimanfaatkan sebaik mungkin untuk mengikat kepercayaan dan mengembangkan kepercayaan yang telah dibangun untuk kesejahteraan. Keadaan sejahtera secara sosial tersusun dari tiga unsur sebagai berikut: Pertama, setinggi apa masalah-masalah sosial dikendalikan. Kedua, seluas apa kebutuhan-kebutuhan dipenuhi. Dan ketiga, setinggi apa kesempatan-kesempatan untuk maju tersedia. ${ }^{7}$ Tiga unsur ini berlaku bagi individuindividu, keluarga-keluarga, komunitas-komunitas, dan bahkan seluruh masyarakat. Midgley menekankan pada pemenuhan hak dasar dan pengaruh ekonomi dalam pembangunan. Pemenuhan hak dasar bisa dilihat dari pemenuhan sandang pangan dan papan.

Jika permasalahan tersebut dari persoalan kapital sosial dimana tingkat kepercayaan masyarakat dengan program pemerintah tidak menemui titik kesepakatan yang seharusnya, sehingga kebutuhan (real needs) dan keinginan masyarakat belum terurai secara jelas, maka pemerintah harus dapat mengembangkan ide pemenuhan hak dasar melalui konsep jaminan sosial yang berkeadilan. ${ }^{8}$ Kombinasi intervensi program dan jaminan hidup akan mengangkat masyarakat miskin di Dusun Sade menjadi lebih baik, dan jika konsep safety net untuk menjaring masyarakat miskin agar tidak jatuh ke jurang yang lebih dalam maka gagasan sistem hibrida-kombinasi intervensi program dengan jaminan hidup bisa menjadi trampolin net sebagai alternatif baru program pengembangan ekonomi melalui pengembangan kapital sosial..$^{9}$ Intervensi pemerintah daerah melalui program lain akan dimaksimalkan secara tepat karena mereka sudah dijamin kehidupan dan kebutuhan dasar melalui program bantuan sosial tanpa syarat ini. ${ }^{10}$

Trust/kepercayaan satu dengan yang lain juga merupakan kapital sosial yang sangat penting dalam menciptakan rasa aman. Melihat bahwa pentingnya peran kapital sosial dalam kehidupan masyarakat Indonesia khususnya di Dusun Sade, maka peneliti menginginkan penelitian lebih mendalam terkait dengan kemungkinan adanya ciri khas dari kapital sosial yang dimiliki oleh masyarakat suku sasak di Dusun Sade yang dapat dimanfaatkan dan dikembangkan sedemikian rupa melalui konsep bantuan sosial tanpa syarat. ${ }^{11}$ Pada akhirnya belum ada definisi yang baku yang mampu menjelaskan suatu fenomena pengembangan kapital sosial suatu daerah berdampak pada pengembangan kehidupan baik dari segi ekonomi, sosial maupun kestruktural masyarakatnya, namun kapital sosial merupakan salah satu unsur penting yang mampu membedakan suatu

${ }^{6}$ Tjip de Jong, Linking Social Capital to Knowledge Productivity: An Explorative Study on the Relationship between Social Capital and Learning in Knowledge-Productive Networks (Netherland: University of Twente, 2010), hlm. 35.

${ }^{7}$ James Midgley, op.cit., hal. 13.

8 Anna Aizer dkk., "The Long-Run Impact of Cash Transfer to Poor Families", American Economic Review, 2016, hlm. 939.

9 Philippe Van Parijs, "Basic Income: A Simple and Powerful Idea for the Twenty-first Century", Politics \& Society, 2004, hlm. 9.

${ }^{10}$ Jessica E. Taaffe dkk., "The impact of cash transfers on livelihoods, education, health and HIV - what's the evidence?", 2017, Development Policy Review, hlm. 3.

${ }^{11}$ Wawancara Informan A1, 15 Maret 2021 di Rumah Informan, Dusun Sade NTB. 
daerah bagaimana merespons dan bertindak ke arah yang lebih baik melalui pengembangan link mereka ke pemerintah ataupun ke pihak pasar/swasta.

\section{Literature Review}

Defenisi tentang pendapatan dasar dalam konsep program perlindungan sosial bantuan sosial adalah bahwa negara memberikan bantuan/jaminan kepada semua warga negara transfer uang tunai, terlepas dari situasi pekerjaan, status sosial, posisi keluarga atau faktor-faktor diskriminatif lainnya. ${ }^{12}$ Lehto menjelaskan bahwa satusatunya kondisi yang membatasi, dalam sebagian besar model pendapatan dasar, adalah 1) tempat tinggal/kewarganegaraan, 2) usia alasan (dewasa), dan 3) kepatuhan pada hukum negara. ${ }^{13}$ Sejalan dengan lehto, Van Parijs memberikan definisi dalam bukunya berjudul Basic Income: A Simple and Powerful Idea for the Twenty-first Century bahwa Pendapatan dasar merupakan pendapatan yang dibayarkan oleh komunitas politik (dalam hal bernegara komunitas politik adalah pemerintah atau negara itu sendiri) kepada semua anggotanya secara individu, tanpa tes atau persyaratan kerja. ${ }^{14}$ National Leagues of Cities mengulas proyek BI dalam Basic Income In Cities A guide to city experiments and pilot project memberikan pengertian bahwa pendapatan dasar adalah suatu pembayaran tunai yang diberikan kepada semua anggota komunitas secara teratur, terlepas dari status pekerjaan atau tingkat pendapatan ${ }^{15}$. Hal ini dimaksudkan agar tetap bersifat individu, tanpa syarat, universal dan sering/berkala. Berdasarkan beberapa pendapat tersebut, dapat disimpulkan bahwa pendapatan dasar adalah bentuk perlindungan sosial yang diberikan komunitas politik dalam konteks negara yaitu pemerintah tanpa adanya persyarat kerja dalam bentuk transfer tunai untuk setiap individu. Selain memahami mengenai berbagai program perlindungan masyarakat yang digagas oleh pemerintah. Pentingnya untuk mempertimbangkan dinamika sosial, konteks dan hubungan kekuasaan di mana jaringan sosial berada. Terdapat tiga jenis modal sosial ${ }^{16}$ yaitu sebagai berikut:

1. Social bounding (perekat sosial) ${ }^{17}$. Social bounding adalah, tipe modal sosial dengan karakteristik adanya ikatan yang kuat (adanya perekat sosial) dalam suatu sistem kemasyarakatan. Social bounding umumnya dalam bentuk nilai, kultur, persepsi, dan tradisi atau adat-istiadat.

2. Social bridging (jembatan sosial) ${ }^{18}$. Social bridging merupakan suatu ikatan sosial yang timbul sebagai reaksi atas berbagai macam karakteristik kelompoknya. Social bridging bisa muncul karena adanya berbagai macam kelemahan yang

\footnotetext{
${ }^{12}$ Francis Fukuyama, op.cit., hal.89

${ }^{13}$ Lehto Otto, Basic Income Around The World The Unexpected Benefits Of Unconditional Cash Transfer (Asi Research Ltd: 2018), hlm. 2.

14 Philippe Van Parijs, op.cit., hal.9

${ }^{15}$ Juliana Bidadanure dkk., Basic Income In Cities: A Quide to City Experiments and Pilot Projects (National League of Cities: 2018), hlm. 7.

${ }^{16}$ Pierre Bourdieu, The forms of capital. In: John G Richardson (ed): Handbook of Theory and Research for the Sociology of Education (New York: Greenwood Press, 1986), hlm 247.

17 Ibid., hlm. 249.

${ }^{18}$ Ibid., hlm. 250.
} 
ada di sekitarnya, sehingga mereka memutuskan untuk membangun kekuatan dari kelemahan.

3. Social linking (hubungan/jaringan sosial) ${ }^{19}$. Merupakan hubungan sosial yang dikarakteristikkan dengan adanya hubungan di antara beberapa level dari kekuatan sosial maupun status sosial yang ada dalam masyarakat. Misalnya: Hubungan antara elite politik dengan masyarakat umum.

\section{B. METODE PENELITIAN}

Penelitian ini menggunakan jenis pendekatan kualitatif. Pendekatan kualitatif dipilih dalam penelitian ini karena dalam penelitian diperlukan untuk menggambarkan peristiwa, perilaku orang atau suatu keadaan lebih rinci dan mendalam. Selain itu penelitian ini juga menggunakan pendekatan analisis literatur dan analisis dokumen terkait.

Peneliti melakukan wawancara secara tidak terstruktur yang memberikan peluang untuk mendapatkan kekayaan informasi yang bisa didapatkan dalam proses wawancara. Dalam praktiknya, wawancara yang dilakukan secara tidak terstruktur atau tidak terlalu patuh pada runtutan pertanyaan akan menciptakan suasana cair saat penggalian data ${ }^{20}$. Namun, peneliti tetap menyiapkan instrumen wawancara yang telah melalui proses uji sebelum kemudian turun lapangan. Panduan ini berguna sebagai guideline peneliti selama melakukan wawancara. Wawancara yang dilakukan peneliti adalah In depth Interview atau wawancara mendalam pada key-Informan dengan topik yang spesifik ${ }^{21}$. Pada konteks penelitian ini, key-Informan didapatkan dengan melakukan penarikan sampel kualitatif dengan cara purposive sampling. Menurut Bryman purposive sampling dalam studi kualitatif pada dasarnya adalah sebuah metode pemilihan informan secara terseleksi mengacu pada pertanyaan penelitian dan sesuai dengan kriteria tertentu ${ }^{22}$. Unit analisis dalam penelitian ini adalah The Mother penerima bantuan sosial dalam program keluarga harapan $(\mathrm{PKH})$ yang ada di Dusun Sade, NTB. Dalam konteks penelitian ini, Dusun Sade merupakan dusun adat yang masih asri adat istiadatnya sehingga dibutuhkan strategi tersendiri untuk dapat menyelami pengalaman mereka. Peneliti sebelumnya telah menetapkan karakteristik informan dalam penelitian ini, namun untuk menemukan informan tersebut peneliti memanfaatkan peran gatekeeper untuk membantu mengantarkan ke informan selanjutnya. Hal ini dilakukan untuk membangun kepercayaan dan kedalaman informasi yang peneliti dapatkan. ${ }^{23}$

Peneliti melakukan wawancara mendalam pada tiga the mother penerima bantuan PKH dan dua orang berpengaruh di Dusun Sade. Untuk menemukan tiga

\footnotetext{
${ }^{19}$ Ibid., hlm. 253.

${ }^{20}$ John Creswell, Research Design: Qualitative, Quantitative, and Mixed Methods Approaches (London: Sage Publication, 2014), hlm. 89.

${ }^{21}$ Ibid., hlm. 99.

22 Alan Bryman, Social Research Methods (United Kingdom: Oxford University Press, 2012), hlm. 113.

${ }^{23}$ Ibid., hlm. 125.
} 
orang informan yang telah diwawancarai, peneliti dibantu seorang gatekeeper ${ }^{24}$ untuk mempermudah akses informasi. Data yang berasal dari the mother ini berfungsi untuk mengetahui dampak adanya bantuan sosial di masyarakat Dusun Sade. Sedangkan, informan orang berpengaruh berfungsi untuk memberikan pengetahuan bagaimana pendapat mengenai bantuan sosial tersebut dan perkembangan di masyarakat.

\section{HASIL TEMUAN DAN PEMBAHASAN}

Gambar 1.1. Kerangka konversi kapital

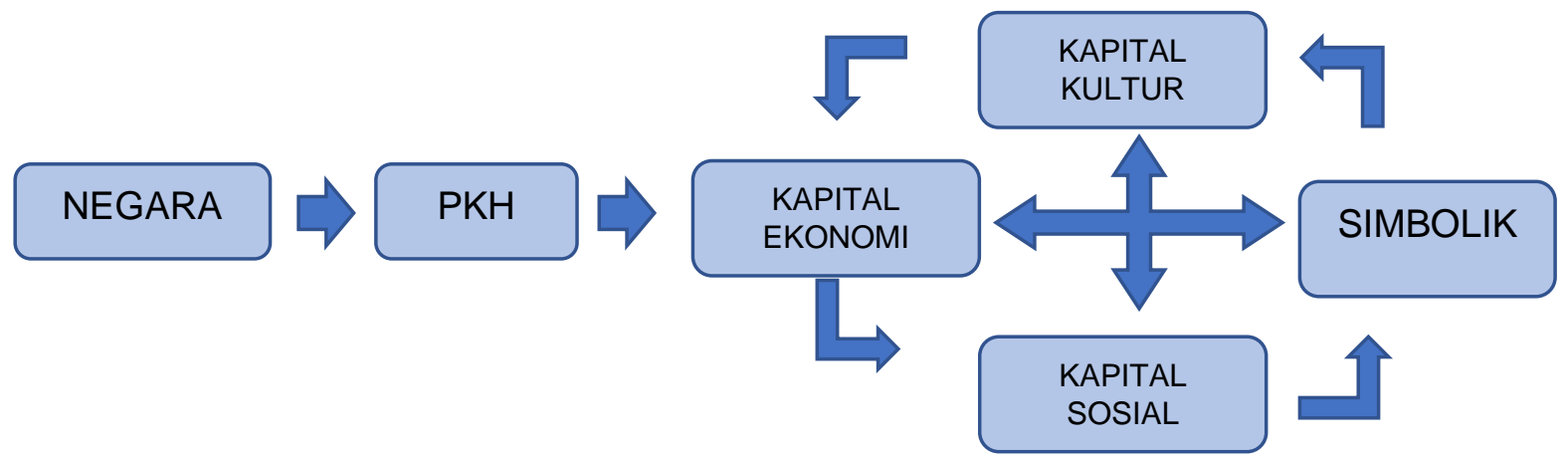

Sumber: (Hasil olahan peneliti, 2021)

Ide ini berawal dari bagaimana bourdieu ${ }^{25}$ menjelaskan konsep konversi kapital dimana kapital dalam field saling berhubungan dan dapat dikonversikan. Dengan meningkatkan kapital ekonomi diharapkan nantinya kapital lainnya dapat berpengaruh positif dimana nantinya akan kembali mempengaruhi kapital ekonomi.

\section{Implementasi Pendapatan dasar}

Pendapatan dasar yang nantinya dilakukan dalam bentuk program bantuan sosial adalah suatu skema perlindungan sosial paling radikal. Negara melakukan aktivitas transfer uang tunai tanpa syarat ke semua warga negara / penduduk di negara tersebut. Gagasan ini bukanlah ide baru, sejumlah filsuf sejak abad keenam belas telah menganjurkan beberapa jenis pendapatan universal minimum untuk mengurangi masalah sosial dan untuk menjamin keadilan sosial ${ }^{26}$. Bahkan di beberapa negara telah mengembangkan konsep pendapatan dasar dengan berbagai macam program seperti NIT (Negative Income Tax) di Amerika dan Kanada, BIG (Basic Income Grant) di India dan masih banyak lagi model program yang mengembangkan ide pendapatan dasar ini.

Pendapatan dasar universal adalah penghasilan yang dibayarkan oleh komunitas politik (dalam hal ini adalah negara/pemerintah) kepada semua anggotanya (masyarakat) berdasarkan individu, tanpa mean test atau persyaratan kerja ${ }^{27}$. Ini adalah

${ }^{24}$ Gatekeeper adalah orang yang membuka pintu pertama kepada informan pertama penelitian yang berfungsi sebagai perantara menuju informan selanjutnya.

${ }^{25}$ Pierre Bourdieu, op.cit., hal. 243.

${ }^{26}$ Arief Anshory Yusuf, The direct and indirect effect of cash transfer: the case of Indonesia (International Journal of Social Economics, 2018), hlm. 783.

${ }^{27}$ Remme J.S. Michelle, Social Capital and Development: Could it Be the Missing Link? (Tilburg University: Thesis, 2005), hlm. 8. 
definisi yang akan saya gunakan dalam mengembangkan program pendapatan dasar di Dusun Sade. Tujuan dari definisi di atas bukan untuk penggunaan kebijakan tetapi untuk mengklarifikasi argumen. Definisi diatas akan terbagi dari berbagai komponen seperti: Pendapatan, Negara/pemerintah sebagai pembayar, masyarakat sebagai yang dibayar, tanpa syarat dan individual.

Pendapatan yang diberikan kepada masyarakat merupakan uang berbentuk cash yang akan diterima per bulannya. ${ }^{28} \mathrm{Hal}$ ini dimaksudkan untuk menjamin kehidupan selama sebulan dan dimanfaatkan hanya untuk memenuhi kehidupannya sehari-hari. Pendapatan perbulan disesuaikan oleh tingkat kebutuhan sesuai dengan perhitungan pengeluaran kebutuhan di daerah tersebut dalam hal ini Dusun Sade. Bisa jadi kebutuhan masyarakat Dusun Sade lebih kecil daripada upah minimum daerah kabupatennya. Walaupun pada beberapa proyek pendapatan dasar ada yang menggunakan per minggu, namun penerimaan masyarakat akan uang cash lebih mudah dalam perhitungan perbulan sesuai dengan kalkulasi dari pendapatan daerah nantinya.

Jika penerima menerima uang cash, maka siapa yang akan memberikan uang cash tersebut. Jawabannya terletak pada negara yang akan melindungi dan memberikan jaminan sosial berupa uang cash tanpa syarat perbulan. Negara dalam hal ini juga pemerintah akan membuat kebijakan fiskal dimana anggaran asli daerah akan dialokasikan pada program Pendapatan Dasar ini. Ketidakcukupan anggaran daerah juga akan didukung oleh kebijakan yang mengharuskan perusahaan dalam kawasan Dusun Sade untuk memprioritaskan program corporate social responsibility mereka dalam bentuk program bantuan sosial. Kerja sama negara dalam hal ini pemerintah daerah NTB akan berkolaborasi dengan pihak privat atau swasta untuk memberikan jaminan sosial melalui program Pendapatan Dasar. Skema anggaran ini akan terus berubah sesuai dengan kemampuan dan potensi daerah nantinya.

Uang cash tersebut akan diberikan kepada mereka yang bertempat tinggal dan warga asli Dusun Sade yang memiliki usaha memproduksi barang lokal. Konsep Pendapatan Dasar pada dasarnya bersifat universal, artinya semua warga atau masyarakat luas harusnya ikut merasakan program Pendapatan Dasar ${ }^{29}$, namun permasalahan lokasi penelitian berfokus pada penurunan kreativitas dan perekonomian warga Dusun Sade. Oleh karenanya program Pendapatan Dasar akan diprioritaskan kepada warga yang memiliki usaha mandiri atau yang disebut lokal dalam menghasilkan produk lokal. Jika Pendapatan Dasar ini mampu mengembangkan potensi dan meningkatkan perekonomian masyarakat yang memiliki usaha bisa jadi akan diperluas kepada warga yang belum memiliki usaha, bahkan bisa jadi nantinya akan diperluas hingga tingkat desa, kelurahan hingga kecamatan. Pada penelitian ini uji wawancara pada mereka yang mendapatkan program $\mathrm{PKH}$, tentunya skema Conditional Cash Transfer/CCT ini sejalan dengan penelitian yang ingin melihat adanya perubahan mendasar dari mereka yang diberikan cash secara cuma-cuma/tanpa syarat. ${ }^{30}$

28 Wawancara Informan SI, 10 Maret 2021 di Rumah Informan Dusun Sade NTB.

${ }^{29}$ Arief Anshory Yusuf, op.cit., hal.784.

${ }^{30}$ Wawancara Informan LA, 10 Maret 2021 di Rumah Informan Dusun Sade NTB. 
Konsep Pendapatan Dasar pada hakikatnya merupakan konsep tanpa syarat atau Unconditional Cash Transfer. Berbeda dengan program yang harus memiliki persyaratan, Pendapatan Dasar lebih menekankan pada jumlah penerima yang menerima program. Tujuan utama Pendapatan Dasar dari berbagai uji coba di negara India dan Namibia berfokus pada peningkatan produktivitas dan rasio pajak ${ }^{31}$. Oleh karenanya program Pendapatan Dasar yang akan diterapkan di Dusun Sade seharusnya bersifat tanpa syarat. Namun, sasaran dari program ini akan diprioritaskan pada warga yang memiliki usaha. Sehingga adanya syarat yang diberikan sebagai bentuk pengelompokan mereka yang menerima bantuan ini. Anggota keluarga akan menerima uang cash sesuai dengan aturan dan kebijakan yang nantinya akan diterapkan. Nominal uang yang diterima akan berbeda juga sesuai dengan kebutuhan individu. Walaupun perhitungan individu namun pembayaran yang dilakukan perbulan akan dilakukan secara gabungan bukan individual. Selain mempersingkat waktu pengiriman juga mempermudah negara dalam melakukan analisis dan evaluasi kebijakan.

\section{Pendapatan Dasar Sebagai Bentuk Peningkatan Ekonomi}

Permasalahan yang ada di Dusun Sade merupakan permasalahan yang kompleks. Ketidakmampuan untuk mengelola intervensi program pemerintah, kemiskinan, pendidikan yang terbelakang hingga pada pendapatan per bulan yang semakin kecil yang membuat kebanyakan dari penduduk Dusun Sade berpindah profesi. Produksi kain tenun, membuat alat tradisional, bertani dan nelayan menjadi pekerjaan utama dari warga Dusun Sade berpindah menjadi tour guide atau bekerja dibidang nirlaba dan migrasi. Penyebab menurunnya produktivitas kreatif Dusun Sade hingga berkurangnya pendapatan perbulan beragam, namun kepala dusun menyampaikan bahwa kebanyakan alih fungsi pekerja akibat gagal panen dan bencana. Ketidaktahuan dan minimnya kreativitas juga menghambat pemasaran produk asli Dusun Sade. Hal itu semua berimbas pada menurunnya pendapatan perbulan dan mengakibatkan banyak dari warga menggunakan modal usaha yang diberikan oleh pemerintah untuk memenuhi kebutuhan sehari-hari. Melihat dari pernyataan kepala Dusun Sade, ada beberapa hal yang menarik:

a. Masyarakat tidak mampu mengelola program pemerintah dikarenakan kesulitan dalam memenuhi kebutuhan dasar, dan

b. Tidak bertemunya kebutuhan dan keinginan masyarakat dengan intervensi pemerintah.

Hal ini berdampak pada hilangnya kepercayaan pada pemerintah yang dibuktikan dari pernyataan kepala dusun bahwa pemerintah hanya memberikan program yang tidak mampu membantu masyarakat dalam memenuhi kebutuhan dasar ${ }^{32}$. Ada banyak program yang masuk salah satunya PNPM mandiri namun bukannya untuk mengembangkan usaha warga lebih memilih untuk membeli kebutuhan dasar. Padahal program yang harusnya untuk mengembangkan usaha,

\footnotetext{
${ }^{31}$ Remme J.S. Michelle, op.cit., hal. 7.

32 Wawancara Informan AT, 11 Maret 2021 di Kantor Balai Adat Dusun Sade NTB.
} 
program untuk membangun infrastruktur jika dikelola secara maksimal akan berdampak pada perekonomian juga. Namun fakta lapangan berkebalikan dari hal yang ideal. Oleh karena itu PENDAPATAN DASAR sebagai salah satu kebijakan program jaminan sosial untuk masyarakat harusnya mampu memberikan ruang kepada masyarakat untuk membenahi diri dan mengembangkan diri. Poin yang akan disampaikan pada program ini:

a. Negara akan memberikan jaminan sosial berupa uang cash untuk memenuhi kebutuhan dasar;

b. Warga yang mendapat Pendapatan Dasar dapat mengembangkan potensi diri dan memanfaatkan program lainnya dengan maksimal tanpa memikirkan kebutuhan dasar;

c. Pemerintah dan warga Dusun Sade dapat menemukan equilibirum dalam kesepakatan kerja melalui Pendapatan Dasar.

Penerapan gagasan Pendapatan Dasar di belahan negara lain juga menemukan hal positif. Seperti awal mula proyek Negative Income Tax di Amerika dan Kanada sampai pada penerapan Basic Income Grant di Namibia sebagai manifestasi konsep Pendapatan Dasar. India ${ }^{33}$ dan Namibia sukses menjalankan konsep Pendapatan Dasar yang mampu merubah perekonomian daerah uji coba Pendapatan Dasar tersebut ${ }^{34}$. Meningkatnya kesadaran akan kesehatan, pendidikan, rasio pajak hingga pada produktivitas kerja.

Tabel 1. Penerapan Pendapatan dasar di India dan Namibia

\begin{tabular}{|c|c|c|c|}
\hline \multirow{3}{*}{ INDIA } & Lokasi & \multirow{2}{*}{\begin{tabular}{l}
\multicolumn{2}{c}{ Model } \\
Memberikan \\
penghasilan dasar \\
universal ( $\$ 4 /$ \\
dewasa, \$ 2 / anak \\
sebulan) selama
\end{tabular}} & Dampak \\
\hline & $\begin{array}{l}\text { Delapan desa } \\
\text { di Madhya } \\
\text { Pradesh }\end{array}$ & & $\begin{array}{l}\text { a. Kesehatan, pendidikan, } \\
\text { nutrisi, indikator ekuitas } \\
\text { yang lebih baik, dan } \\
\text { pengurangan hutang dan } \\
\text { pekerja terikat }\end{array}$ \\
\hline & & $\begin{array}{l}\text { kurang lebih } 18 \\
\text { bulan }\end{array}$ & $\begin{array}{l}\text { b. Peningkatan investasi } \\
\text { ekonomi (benih yang lebih } \\
\text { baik, mesin jahit, perbaikan } \\
\text { peralatan, pendirian toko) }\end{array}$ \\
\hline & & & $\begin{array}{l}\text { c. Peningkatan pekerjaan yang } \\
\text { menghasilkan pendapatan }\end{array}$ \\
\hline NAMIBIA & Desa Otjivero & $\begin{array}{l}\text { proyek } \\
\text { percontohan } \\
\text { transfer tunai tanpa }\end{array}$ & $\begin{array}{l}\text { a. Pengurangan } \\
\text { kelaparan, } \\
\text { kemiskinan }\end{array}$ \\
\hline
\end{tabular}

33 Saksham Khosla, India's Pendapatan dasar: Bedeviled by the Details (Carnegie India, 2018), hlm. 17.

${ }^{34}$ Karl Widerquist, The Basic Income Grant as Social Safety Net for Namibia: Experience and lessons from around the world (Georgetown University), hlm. 7. 


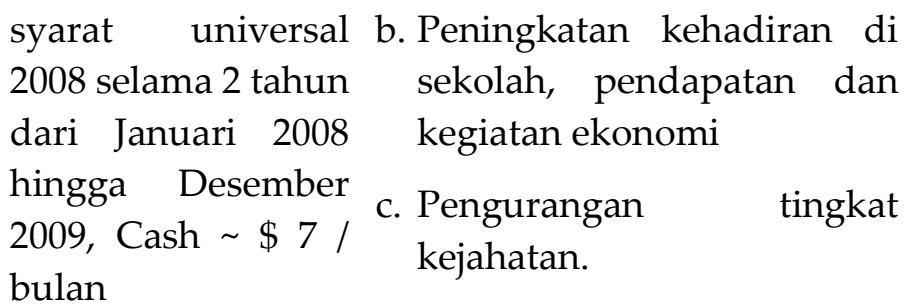

Sumber: Laporan HaasInstitute dan Hasil Penelitian Lesson learn George University

Kesamaan demografi dan geografi menjadi alasan utama mengapa lokasi Dusun Sade ini sesuai dengan laporan dan hasil penelitian Pendapatan Dasar sebelumnya di negara India dan Namibia, terlebih namibia berfokus pada masyarakat yang bekerja untuk meningkatkan rasio pajak mereka. Hasil dampak positif ini juga tidak hanya pada dua negara tersebut, namun di Amerika-Kanada, Alaska hingga Finlandia juga berdampak positif. Walaupun pada kenyataannya selalu ada pro dan kontra mengenai Pendapatan Dasar.

\section{Gambar 1.2. Kerangka Pemikiran Penelitian}

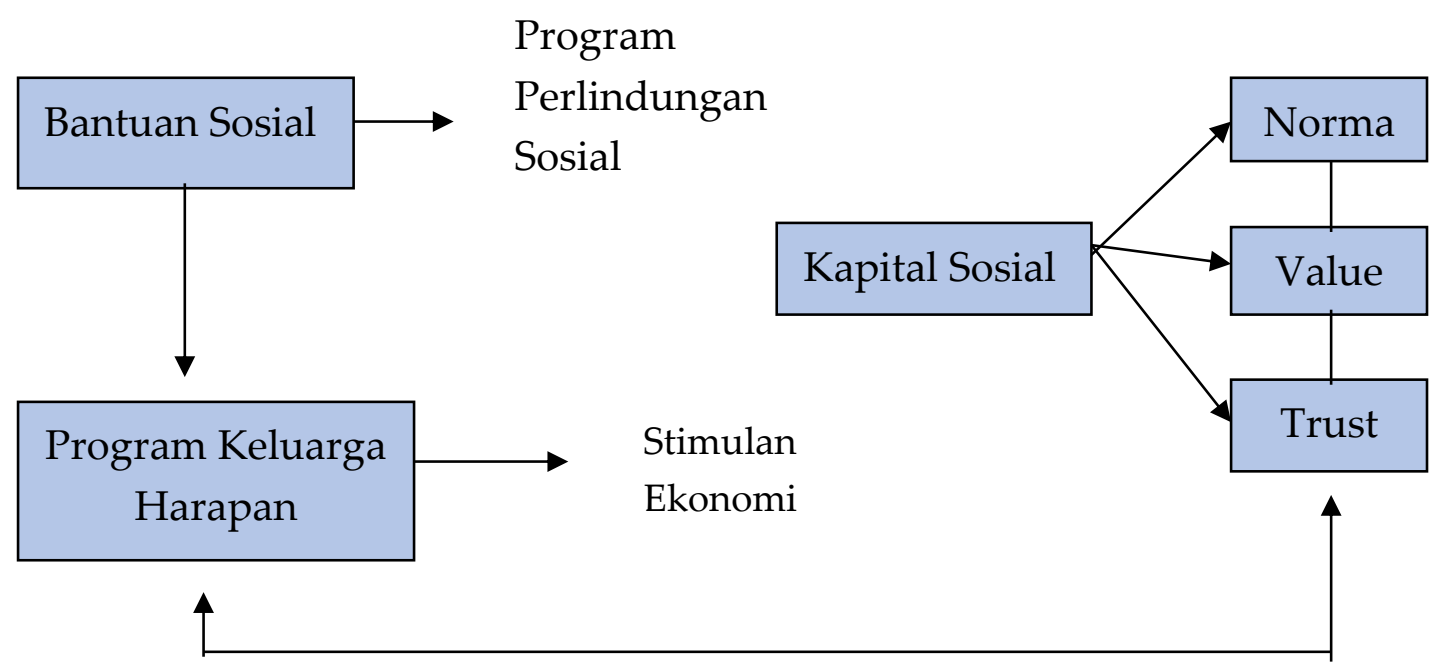

Government Trust

Sumber: Hasil Olahan Peneliti, 2021

Adanya konsep pendapatan dasar melalui bantuan sosial banyak sudah diujicobakan di berbagai negara memberikan alternatif pilihan dalam mengentaskan kemiskinan dan meningkatkan perekonomian ${ }^{35}$. Pembuktian di India, Namibia, Alaska hingga Amerika-Kanada membuat kita perlu penelitian lebih lanjut mengenai konsep BI agar dapat di replikasi dan menjadi penelitian percontohan bagi penelitian lanjutan. Skema BI dalam mengembangkan potensi kapital sosial menegaskan bahwa ada banyak gagasan radikan yang mampu mengangkat warga negara/individu keluar dari zona kemiskinan. Safety net yang selama ini hanya bekerja untuk menangkap mereka yang terjatuh ke garis kemiskinan kini berubah menjadi Trampolin Net dimana tidak hanya

${ }^{35}$ Philippe Van Parijs, op.cit., hal. 10. 
menjaring namun dilentingkan kembali ke posisi semula atau bahkan masuk dalam kategori tidak miskin dan wajib bayar pajak.

Tujuan dasar dari ide ini bukanlah pengubahan perilaku melainkan meningkatkan produktifitas warga dan menaikan perekonomian yang berujung pada penambahan pajak negara. BI diletakan di asas kepercayaan masyarakat akan negara dan norma-norma adat yang memberikan dampak keintiman dalam menajalankan program. Indonesia yang penuh rasa kekeluargaan harusnya mampu memberikan konsep family-based dalam memberikan bantuan, bukan lagi atas kemauan negara tanpa adanya analisis yang mendalam. Pemerintah harus lebih sadar akan kebutuhan riil masyarakat bukan pada penambahan target untuk kinerja semata. Konsep money follow program harus digerakkan karena akan berfokus pada program, tidak lagi menggunakan money follow function yang hanya berfokus pada fungsi. ${ }^{36}$

Permasalahan intervensi program yang tidak tepat sasaran tidak efektif bahkan sampai pada kegagalan program sedikit tidaknya berpengaruh oleh satu faktor yang sering terlupakan yaitu kapital sosial. Memperkuat kepercayaan masyarakat akan pemerintah memberi dampak pada kekuatan ekonomi suatu daerah. Gejolak persoalan sosial di masyarakat tidak terlepas dari tingkat kepercayaan publik terhadap pemerintah atau negara. Hal ini juga dirasakan di Dusun Sade dimana masyarakat Dusun Sade belum memaksimalkan intervensi program yang ada dikarenakan masyarakat lebih memilih untuk memenuhi kebutuhan sehari-hari yang makin kini makin memburuk. Faktor alam, pendidikan hingga kerja sama yang buruk memperkeruh keadaan masyarakat.

Keadaan ini akan selalu seperti itu jika masyarakat tidak diberikan pilihan pasti mengenai jaminan hidup mereka. Meningkatkan dan menguatkan potensi kapital sosial dimulai dari menguatkan bonding mereka satu dengan yang lain. Kebiasaan dan norma-norma adat harus dimanfaatkan sebaik mungkin untuk menunjang keberhasilan program. Ketidakmampuan masyarakat dalam melakukan birdging seharusnya menjadi langkah besar bagi pemerintah daerah dalam membuat kebijakan. Pendapatan Dasar akan menjadi katalisator dalam mempercepat bridging dikarenakan adanya rasa aman dan jaminan hidup kepada masyarakat. Jaminan itu yang membuat mereka berani berinovasi, berani mencoba dan berani melangkah kedepan dengan kreativitasnya dalam melakukan usaha ${ }^{37}$. Seringkali masyarakat Dusun Sade mengutamakan penjualan produk dari turis yang datang daripada menjual menggunakan akses teknologi dan bekerja sama dengan lembaga nirlaba lainnya.

Bantuan permodalan untuk pengembangan usaha lagi-lagi teralihkan oleh kebutuhan utama yang sangat mendasar, yang seharusnya sudah terpenuhi. Adanya konsep dan program Pendapatan Dasar ini diharapkan masyarakat yang telah memiliki usaha tidak lagi menggunakan bantuan dengan asal-asalan tanpa perhitungan. Pendapatan Dasar akan menjamin hidup masyarakat dan membantu masyarakat lebih kreatif dan inovatif dalam berproduksi. Pendapatan Dasar ini nantinya menjadi titik temu antara pemerintah dan masyarakat dalam bekerja sama dan menjawab persoalan-

\footnotetext{
${ }^{36}$ Francis Fukuyama, op.cit., hal.96

${ }^{37}$ Karl Widerquist, op.cit., hal. 10.
} 
persoalan sosial dan ekonomi yang selama ini masih menjadi polemik. Disatu sisi pemerintah merasa masyarakat tidak mampu menggunakan bantuan dengan maksimal disisi yang lain masyarakat menilai bantuan pemerintah tidak tepat sasaran dan hanya buang-buang anggaran. Masyarakat Dusun Sade menginginkan adanya bantuan yang mampu membantu mereka untuk mengurusi masalah kebutuhan dasar, masalah pendidikan hingga kesehatan, sehingga mereka mampu bersaing, berinovasi dan melakukan kerja sama dengan lembaga lain untuk memanfaatkan bantuan pemerintah dan mengembangkan usaha mereka. ${ }^{38}$

Kerja sama antar kelembagaan dari pemerintah, swasta dan masyarakat akan membuat Pendapatan Dasar menjadi salah satu tombak dalam perubahan perekonomian lokal. Pemerintah mampu membuat kebijakan khusus mengenai pengelolaan CSR dalam membantu pengadaan anggaran Pendapatan Dasar dan pemerintah dapat menarik pajak yang sudah mampu masuk ke dalam garis layak bayar pajak. Ujung dari Pendapatan Dasar adalah masyarakat mampu berkontribusi pada negara melalui pajak. Hal ini dikarenakan Pendapatan Dasar berfokus pada peningkatan produktivitas warga yang memiliki usaha. Mekanisme ini akan berhasil jika masyarakat dan pemerintah dapat saling percaya dan mengembangkan potensi kapital sosial yang sudah ada. Adanya Pendapatan Dasar tidak akan mengubah bonding masyarakat yang sudah ada, bahkan akan meningkatkan bridging mereka dengan meminimalisir resiko kehilangan bonding. Poin utamanya terletak pada jaminan hidup masyarakat yang sudah diberikan oleh negara.

Rata-rata masyarakat memanfaatkan bantuan yang diberikan dari pemerintah khususnya program PKH untuk memenuhi kebutuhan hidup sehari-hari. Itu pun biasanya langsung dihabiskan karena memang ada yang memiliki hutang yang harus dibayarkan, masyarakat masih belum mampu untuk menabung bantuan dari pemerintah tersebut, apalagi untuk dijadikan modal usaha. Setelah mendapatkan program Pendapatan Dasar, terjadi perubahan yang cukup signifikan baik dari segi ekonomi, sosial, maupun hal lainnya. Dari segi ekonomi, yang paling dirasakan adalah masyarakat sangat terbantu dalam pemenuhan kebutuhan pokok sehari-hari untuk makan, membeli lauk, dan sebagainya. Dari segi sosial, masyarakat menjadi lebih peduli dengan sesama. Dari segi pola pikir, masyarakat jadi semakin menyadari akan pentingnya kesehatan bagi anak, pentingnya pendidikan bagi anak, pentingnya kuliah, dan lain-lain. Perubahan pola pikir dalam masyarakat yang sebelumnya tidak terlalu mementingkan pendidikan dan kesehatan pada anak, sekarang menjadi lebih memperhatikan hal-hal tersebut. Masyarakat saat ini menjadi lebih peduli dengan tetangganya, karena memang tetangga bukan orang lain, masih memiliki hubungan keluarga. Jadi, tanpa ada instruksi dari tokoh masyarakat atau tokoh adat disini, mereka dengan sukarela memberikan sebagian bantuan mereka kepada tetangganya yang tidak mendapatkan bantuan. Hal ini sudah ditanamkan sejak nenek moyang dulu, kalau satu makan semua harus makan, kalau satu sakit semua sakit.

${ }^{38}$ Wawancara Informan AT, 11 Maret 2021 di Kantor Balai Adat Dusun Sade NTB. 


\section{KESIMPULAN}

Adanya konsep Pendapatan Dasar yang sudah diujicobakan di berbagai negara memberikan alternatif pilihan dalam mengentaskan kemiskinan dan meningkatkan perekonomian. Pembuktian di India, Namibia, Alaska hingga Amerika-Kanada membuat kita perlu penelitian lebih lanjut mengenai konsep Pendapatan Dasar agar dapat di replikasi dan menjadi penelitian percontohan bagi penelitian lanjutan. Skema Pendapatan Dasar dalam mengembangkan potensi kapital sosial menegaskan bahwa ada banyak gagasan radikal yang mampu mengangkat warga negara / individu keluar dari zona kemiskinan. Safety net yang selama ini hanya bekerja untuk menangkap mereka yang terjatuh ke garis kemiskinan kini berubah menjadi Trampolin Net dimana tidak hanya menjaring namun dilentingkan kembali ke posisi semula atau bahkan masuk dalam kategori tidak miskin dan wajib bayar pajak.

Tujuan dasar dari Pendapatan Dasar bukanlah pengubahan perilaku melainkan meningkatkan produktifitas warga dan menaikan perekonomian yang berujung pada penambahan pajak negara. Pendapatan Dasar diletakan di asas kepercayaan masyarakat akan negara dan norma-norma adat yang memberikan dampak keintiman dalam menajalankan program. Indonesia yang penuh rasa kekeluargaan harusnya mampu memberikan konsep family-based dalam memberikan bantuan, bukan lagi atas kemauan negara tanpa adanya analisis yang mendalam. Pemerintah harus lebih sadar akan kebutuhan riil masyarakat bukan pada penambahan target untuk kinerja semata. Konsep money follow program harus digerakan karena akan berfokus pada program, tidak lagi menggunakan money follow function yang hanya berfokus pada fungsi.

Pengaplikasian program bantuan sosial yang dapat dijadikan program pendapatan dasar harus diawali dengan asesmen yang mendalam mengenai potensi dan masalah yang ada hingga pada penerapan mekanisme pembayaran.

Tabel 2. Tahapan Implementasi Program Pendapatan dasar

\begin{tabular}{|c|c|c|}
\hline Tahapan & Desain & Penjelasan \\
\hline Asesmen & $\begin{array}{l}\text { - Pemetaan terhadap tujuan, masalah dan } \\
\text { potensi } \\
\text { - Menyusun kerangka teori (theory of } \\
\text { Change) }\end{array}$ & \\
\hline \multirow[t]{2}{*}{ Perencanaan } & $\begin{array}{l}\text { - Melibatkan komunitas dalam } \\
\text { perencanaan dengan membuat aturan- } \\
\text { aturan PENDAPATAN DASAR } \\
\text { (memperkuat ikatan masyarakat dan } \\
\text { pemerintah) }\end{array}$ & $\begin{array}{l}\text { Public-private partnership, } \\
\text { Creative fundrising, Collaborate }\end{array}$ \\
\hline & $\begin{array}{l}\text { - Membuat mekanisme funding } \\
\text { (pembayaran) }\end{array}$ & \\
\hline Implementasi & $\begin{array}{l}\text { Kolaborasi dengan pihak terkait } \\
\text { (masyarakat dan Swasta) }\end{array}$ & $\begin{array}{l}\text { Pengimplementasian aturan } \\
\text { dari dan untuk masyarakat }\end{array}$ \\
\hline
\end{tabular}


yang menerima program

PENDAPATAN DASAR

\begin{tabular}{ll}
\hline Monev & $\begin{array}{l}\bullet \text { Pengawasan berkala melalui skema } \\
\text { laporan per-tiga-bulan }\end{array}$ \\
& $\bullet$ Evaluasi per individu \\
\hline Bimbingan & $\begin{array}{l}\text { Adanya pendampingan program dan } \\
\text { Lanjut }\end{array}$ \\
& reward bagi yang telah berhasil masuk \\
& dalam kategori layak bayar pajak
\end{tabular}

Sumber: Hasil Analisis Peneliti, 2021

Dengan memahami potensi dan masalah Dusun Sade, penguatan melalui Pendapatan Dasar dan mengembangkan kapital sosial akan lebih efektif. Kerja sama antar lembaga dan meningkatkan kesadaran menjadi kunci utama. Pendapatan Dasar bukanlah program yang sempurna namun Pendapatan Dasar mampu mengubah keadaan secara singkat melalui pemberian cash langsung yang bertujuan. Kelebihan program ini terletak pada kemudahan dalam pemberian bantuan dan ekuitas layanan program. Bagi mereka yang bersemangat dalam bekerja Pendapatan Dasar menjadi daya lenting yang sangat bagus, namun bagi mereka yang tidak bersemangat dalam bekerja setidaknya mampu mengurangi tingkat kriminalitas akibat tidak terpenuhinya kebutuhan dasar. Kesehatan yang membaik karena masyarakat mampu membeli kebutuhan makanan yang berkualitas hingga pada pendidikan yang membaik karena kemudahan dalam memilih transportasi. Banyak hal yang positif dari Pendapatan Dasar namun perlu diingat kunci dari keberhasilan program adalah peletakan asas kapital sosial yang baik terlebih dahulu.

\section{SARAN}

Adanya bukti spesifik dari hasil olah data interview beberapa kunci utama di masyarakat sade membuktikan bahwa penerapan bantuan sosial baik itu tanpa syarat maupun yang bersyarat memiliki dampak yang signifikan. Analisis kapital sosial memberikan gambaran nyata akan kepercayaan akan suatu program jika berdampak dan mereka diberikan akses penuh dalam pengelolaannya. Jaminan yang diberikan melalui bantuan sosial juga memberikan rasa aman pada masing-masing individu dalam keluarga dalam menghadapi berbagai rintangan. Oleh karenanya sangat penting bagi pemangku kebijakan baik level lokal maupun nasional melihat dampak nyata yang diberikan program perlindungan sosial dalam bentuk bantuan sosial pendapatan dasar untuk memberikan kesempatan pada masyarakat miskin berpartisipasi dalam roda ekonomi lokal maupun nasional. Dengan stimulan ekonomi program perlindungan sosial dapat melentingkan kapabilitas masyarakat miskin kearah lebih baik. Harapannya kedepan semakin banyak program bantuan sosial yang tepat guna, tepat sasaran, tepat waktu dan tepat anggaran yang sifatnya menjamin dan melindungi masyarakat miskin yang berhak dilindungi. 


\section{REFERENSI:}

\section{Buku:}

Bryman, A. (2012). Social Research Methods. Oxford University Press, 4th edition.

Cresswell, J.W. (2014). Research design: qualitative, quantitative, and mixed methods approaches 4 ed. London: Sage Publication Ltd.

Fukuyama, F. (1995). Trust: the social virtues and the creation of prosperity. New York: Free Press.

Midgley, James. (1995). Social Development: The Developmental Perspective in Social Welfare. London: Sage Publication Ltd.

Lehto, Otto. (2018). Basic Income Around The World The Unexpected Benefits Of Unconditional Cash Transfers. Asi (Research) Ltd.

Bourdieu, Pierre: The forms of capital. In: John G. Richardson (ed.): Handbook of Theory and Research for the Sociology of Education. New York: Greenwood Press 1986, s. 241-258.

\section{Publikasi Ilmiah Thesis:}

De Jong, T. (2010). Linking social capital to knowledge productivity: an explorative study on the relationship between social capital and learning in knowledge-productive networks. University of Twente: Thesis.

Michelle J.S. Remme. (2005). Social capital and development: could it be the missing link?. Tilburg University: Thesis.

Prihandini, Novita. 2017. Identification of asset (social, natural, financial, phisic, human) in tourism sade village in the regency of central lombok. Thesis: University of Brawijaya.

\section{Artikel Jurnal:}

Aizer, A., Eli, S., Ferrie, J., \& Lleras-Muney, A. (2016). The Long-Run Impact of Cash Transfers to Poor Families. American Economic Review, 106(4), 935-971. doi:10.1257/aer.20140529Akçomak, Semih. (2009). The impact of social capital on economic and social outcomes.

Bidadanure, Juliana et al., 2018. Basic Income In Cities: A Quide to City Experiments and Pilot Projects. National League of Cities

Khosla, S. (2018). India's Pendapatan dasar: Bedeviled by the Details. Carnegie India

Putnam, R. D. (1995). Bowling alone: America's declining social capital. Journal of Democracy

Sari, K.M., \& Nugroho, S., (2018). Dampak Sosial Budaya Pengembangan Dusun Sade Sebagai Dusun Wisata Di Kabupaten Lombok Tengah. Jurnal Destinasi Wisata, 6(1). 
Taaffe, Jessica \& Longosz, Andrew \& Wilson, David. (2017). The impact of cash transfers on livelihoods, education, health and HIV - what's the evidence? Development Policy Review. 35. 10.1111/dpr.12253.

Van Parijs, P. (2004). Basic Income: A Simple and Powerful Idea for the Twenty-First Century. Politics \& Society, 32(1), 7-39. doi:10.1177/0032329203261095

Yusuf, Arief Anshory. (2018). The direct and indirect effect of cash transfer: the case of Indonesia. International Journal of Social Economics. Vol. 45 No. 5, pp. 793807.

Zuleta Ferrari, Mariana. (2012). "Social capital, trust and legal institutions". 10.13140/RG.2.2.26192.51208.

\section{Publikasi Organisasi:}

Narayan, Deepa; Grootaert, Grootaert; Nyhan Jones, Veronica; Woolcock, Michael. 2004. Measuring Social Capital : An Integrated Questionnaire. World Bank Working Paper;No. 18. Washington, DC: World Bank. (c) World Bank. https://openknowledge.worldbank.org/handle/10986/15033 License: CC BY 3.0 IGO."

Karl Widerquist, The Basic Income Grant as Social Safety Net for Namibia: Experience and lessons from around the world (Georgetown University), hlm. 7.

Badan Pusat Statistik. 2015. Angka Pengangguran di Dusun Sade Kabupaten Lombok Tengah Nusa Tenggara Barat (Indonesia: Publikasi BPS, 2015).

\section{Sumber lainnya:}

Aplikasi ePKH 